\title{
THE IDEA OF GLOBAL PUBLIC LAW: RESPONSE TO UNBOUND SYMPOSIUM ESSAYS
}

\author{
Devika Hovell*
}

Law abhors a vacuum. Lawyers (including international lawyers) have constructed their profession around the fiction that such a thing is impossible. ${ }^{1}$ Where gaps emerge in a legal framework, lawyers face the task of filling it, compromised by the additional hurdle of having to pretend there was no gap in the first place.

The challenge has intensified with the ever-widening and deepening accountability gap that has accompanied the growth of global governance. In the period between H.G. Wells' writing of The New World Order and the drafting of Security Council resolutions 827, 1267, 1373, and 1540, global governance has evolved from an idea of utopian/dystopian fiction to reality. In a recent article in the American Journal of International Law on "Due Process in the United Nations," I argue that as legal academics we are justified in taking a more architectural role in proposing a legal framework to fill the good-governance-size hole in this emerging tier of governance. Essayists in the AJIL Unbound Symposium convened in response to my article raised interesting (and fairly fundamental) challenges to the methodology proposed. ${ }^{2}$ The hosts of the symposium kindly offered me the chance to respond-I took them up. There may be gaps in international law, but never silences. ${ }^{3}$

When international organizations mushroomed in the wake of World War II, the shift was not greeted as legally revolutionary. Scholarship in the post-war era recognized these organizations as quite simply the agents of states- "loose associations for occasional specific joint action." International organizations merely exercised "functional authority" and law's role was limited to determining whether organizations had acted within the functions ascribed to them. ${ }^{5}$ The legal dynamic at the heart of the theory of functionalism was an international law staple: the relationship between states in their collective (international organization) and singular (member state) forms. Yet, shortly after the turn of the millennium, José Alvarez invited international lawyers to face a new reality. He cautioned that international organizations were increasingly behaving more like Mary Shelley's Frankenstein, established to fulfill certain functions, though gradually developing into a powerful and uncontrollable force beyond the vision of their architects. ${ }^{6}$ No longer regarded as benign apolitical entities, many international organizations were emerging as independent variables-autonomous political entities

* Associate Professor, London School of Economics and Political Science. My thanks to Claire Charters for taking the time to discuss this piece.

Originally published online 26 August 2016.

${ }^{1}$ See Roger O'Keefe's enduring satire of international lawyers: Roger O'Keefe, Once upon a time there was a gap..., EJIL: TALK! (Dec. $8,2010)$.

${ }^{2}$ Devika Hovell, Due Process in the United Nations, 110 AJIL 1, 2 (2016).

${ }^{3}$ O'Keefe, supra note 1.

${ }^{4}$ David Mitrany, The Functional Approach to World Organization, 24 INT'L AFF. 350, 351 (1948).

5 See, e.g., Certain Expenses of the United Nations (Article 17, Paragraph 2, of the Charter), Advisory Opinion, 1962 ICJ REP. 151 (July 20).

${ }^{6}$ José E. AlvareZ, INTERNATIONAL ORGANIZATIONS AS LAW-MAKERS 585 (2005). 
exercising a form of public authority. ${ }^{7}$ The legal dynamic shifted from one between the organization and its member states to one between the organization and "the world around it." 8 The question is this: how should international law (and lawyers) respond?

Writ large, my argument is that we need to recognize a discrete field of legal knowledge, which I will call global public law. The field is less technical than international institutional law, more normatively oriented than global administrative law, less tied to domestic legal structures than global constitutional law, but built instead on a positive theory of international authority. In methodological terms, I argue that global public law is an emerging field to which the traditional rules of international law source methodology are not suited. The idea, drawing on Martin Loughlin's Idea of Public Law, is that a positive theory of public law for the global context should not be a theory of positive law. ${ }^{9}$ Where the task is to develop principles to regulate and sustain global governance structures, reliance on traditional positivist source methodology considerably narrows the boundaries of the subject (including the question as to who is a proper subject or agent of international authority) and evades significant value choices associated with the development of these structures. I propose instead a "value-based" approach to the development of principles of global public law. My article, using due process as a focal point, contrasts three value-based models of due process (instrumentalist, dignitarian, and public interest approaches). Applying these models to the targeted sanctions and Haiti cholera contexts, I expose how the choice of mechanism also entails underlying choices about conceptions of international community, the role of law, and the appropriate balance between values in the global governance setting.

Three essayists of the AJIL Unbound Symposium responding to my article disagreed, not purely with the methodology I propose, but seemingly also with the idea of "normative theorizing" about relevant legal principles at all. As Alexandra Huneeus notes in the introduction to the symposium, "[i]t is interesting-and perhaps a symptom of the empirical turn in the study of international law- that all three symposium essayists seem wary of normative theorizing, preferring to grapple with Hovell's argument through analysis of case studies." 10 Antonios Tzanakopoulos is the most strident. He describes the article as a "highly theorized (and, if I may venture even at the outset, perhaps a bit stylized)" contribution to "the debate regarding the 'accountability' (whatever the term may mean) of international organizations." 11 Tzanakopoulos provides an alternative reading, rejecting "deep theorizing about due process" and inviting us to content ourselves with the "organic emergence and evolution of a remedy through a pattern of defiance, threats, and ultimately negotiation between the Security Council and states, pushed on by their courts, primarily, and also by public opinion or relevant engaged interest groups." 12 He cautions that "we should not be too quick to dismiss the law and (descriptive) focus on state practice in favor of (normative) theoretical appeal."13 Joy Gordon's essay provides an interesting historical perspective on the Iraq sanctions regime (1990-2003), demonstrating how "the lack of due process allowed powerful states on these committees to obscure their roles and avoid accountability." 14 Yet her overall approach indicates implicit agreement with Tzanakopoulos' line, concluding that " $[\mathrm{t}]$ he problem is not the lack of a shared value-based theory of due process, but a lack of political will

\footnotetext{
${ }^{7}$ Jan Klabbers, Theorizing International Organizations, in THE OXFORD HANDBOOK OF THE THEORY OF INTERNATIONAL LAW 618 (Anne Orford \& Florian Hoffmann eds., 2016).

${ }^{8} \underline{I d}$. at 620 .

${ }^{9}$ Martin Loughlin, The Idea of Public Law 155 (2004).

10 Alexandra Huneeus, Introduction to Symposium on Devika Hovell, "Due Process in the United Nations", 110 AJIL UnBOUND 1, 2 (2016).

11 Antonios Tzanakopoulos, Theorizing or Negotiating the Law?: A Response to Devika Hovell, 110 AJIL UnBOUnd 3, 3 (2016).

${ }^{12} \underline{I d}$. at 6 .

${ }^{13} \underline{I d}$. at 7.

${ }^{14}$ Joy Gordon, Due Process and the Iraq Sanctions: A Response to Devika Hovell, 110 AJIL UnBound 13, 13 (2016).
} 
on the part of powerful states." 15 Rosa Freedman sees more scope for both normative and empirical work on these sorts of questions, though "Hovell's focus on only the normative foundations of due process is insufficient" and that "[r] $]$ ather than starting from scratch, we must focus on and address flaws in the existing mechanisms and in the system as a whole in order to give effect to due process in UN decision-making on peacekeeping disputes." 16 Freedman concludes that the challenge is to ensure that normative and empirical work are engaged in "fruitful exchanges that are beneficial at the theoretical and practical levels." 17

With Freedman, I couldn't agree more. I resist the idea that we are on some academic super-highway, where we either make an "empirical turn" or end up on the normative soft shoulder. Many of us left a career in practice to become academics, not as an act of abandonment of practical concerns, but out of a desire to contribute to disciplinary maintenance, renewal, and innovation from the independent vantage point that academia offers. Article 38(1)(d) of the ICJ Statute arguably carves out a distinct role for academics in this respect. Shaffer and Ginsburg in their article "The Empirical Turn in Legal Scholarship" make the strong point that "given international law's normativity is aimed at changing behavior, it makes sense to assess international law empirically regarding the conditions of its effectiveness." 18 Yet they emphasize that "the empirical turn is not a-theoretical." 19 As I understand Shaffer and Ginsburg's aim, it is not to foreclose normative theorizing, but to narrow the gap — and perhaps to make explicit the necessary relation-between abstract theory and empirical assessment of practice: "although one needs to start with higher-level principles and values regarding what one wishes to accomplish, one also needs to think more concretely-closer to the ground and based on experience-about implementation and about what mechanisms and tools are likely to work best in any particular context." ${ }^{20}$ Far from being a counterpoint, Shaffer and Ginsburg's approach is the type of scholarship manifesto I would happily sign on to.

My deliberately normative focus was not chosen as a rebuff to empirical work, but out of a sense we have skipped the normative step. As Jan Klabbers remarks in his entry in the recently-published Oxford Handbook of the Theory of International Law, "[i]nternational organizations lawyers are, as a general rule, not terribly interested in matters of theory." Much of the law of international organizations, he notes, has been developed by practitioners, "responding to practical challenges, often in piecemeal fashion and through mimicry and comparison." 21 Despite Tzanakopoulos' Panglossian perspective on this method, the empirical results are far from satisfactory. With the ECJ's 2008 judgment in Kadi at the heart of his analysis-rightly identified as the trigger for the establishment of the Office of the Ombudsperson in the Security Council sanctions context-Tzanakopoulos notes that "the point here is that the most appropriate mechanism will emerge through negotiations seeking a viable balance of the conflicting interests, rather than through theorizing in abstracto about models, approaches, publics, and values." 22 Yet he fails to mention that the Ombudsperson mechanism took over a decade to achieve and only applies to one of thirteen targeted sanctions regimes. He also fails to make explicit the normative assumptions underlying his claim that this mechanism is emerging as the most "acceptable." In its 2013 Kadi II judgment, the ECJ rejected the Ombudsperson as an adequate mechanism finding that nothing short of "a declaration from a court" would suffice, demonstrating that we

\footnotetext{
${ }^{15} \underline{I d}$.

${ }^{16}$ Rosa Freedman, UN-Accountable?: A Response to Devika Hovell, 110 AJIL UnBound 8, 9, 12 (2016).

${ }^{17} \underline{I d}$. at 12 .

18 Gregory Shaffer \& Tom Ginsburg, The Empirical Turn in Legal Scholarship 106 AJIL 1, 9 (2012).

${ }^{19} \underline{I d}$. at 1 .

${ }^{20} \underline{I d}$. at 45 .

${ }^{21}$ Klabbers, supra note 7, at 630, 618.

22 Tzanakopoulos, supra note 11 , at 6 .
} 
still have an impasse between Council and European courts as to the most appropriate review mechanism. ${ }^{23}$ In the Haiti cholera setting, the practical (lack of) result has so far taken six years to achieve, and counting. In a whiplash week for Haiti cholera victims, the United Nations finally acknowledged its role in the cholera epidemic on August 17, the day before a New York court upheld UN immunity in the class action initiated by the victims' legal representatives. ${ }^{24}$ If we continue along this line, law and courts threaten to become part of the problem, not the solution.

From targeted sanctions to the Haiti cholera controversy to sexual abuse by UN peacekeepers and beyond, there is a crisis of accountability in UN decision-making. The crisis is political in origin and nature. Yet law has a distinct role to play in identifying and maintaining political authority structures. ${ }^{25}$ The standard account of the authority of international law, based on state consent, is under sustained attack. Başak Çali and Nicole Roughan have produced two excellent books laying the groundwork for conceptual and normative accounts of the authority of international law (both rooted in practical contexts) which provide a contemporary foundation for all future work on the topic. ${ }^{26}$ According to Çali, "[m]ainstream international law has offered a theoretically impoverished account of its authority." 27 Similarly, functionalism appears to have outlasted its utility in explaining the authority of international organizations, if it ever did. Felix Cohen compared functionalism in law to functionalist architecture, which is "likewise a repudiation of outworn symbols and functionless forms that have no meaning-hollow marble pillars that do not support, fake buttresses, and false fronts." 28 Drawing on Cohen's work, Anne Orford notes that, just as positivism left the law homeless in Weimar Germany, so functionalism has left international law "subjectless and thus homeless." ${ }^{29}$ In the Security Council setting, the source of the Security Council's authority, including the question of who is the proper subject of its authority, is a load-bearing question. The challenge for international lawyers is not to "speak power to power," as Tzanakopoulos suggests, but to convert power to authority. International law (and international lawyers) must not duck the challenge of developing legal principles that extend beyond the edicts of the powerful. Instead the aim should be to develop a durable legal framework for governing institutions that aspires to work at one remove from power-wielders and embraces the precepts of right conduct. ${ }^{30}$

\footnotetext{
23 Joined Cases C-584/10 P, C-593/10 P \& C-595/10 P, Comm'n v. Kadi, ECLI:EU:C:2013:518., para 134.

${ }^{24}$ Georges v. United Nations, No 15-455, (2d Cir. Aug. 18, 2016).

25 LOUGHLIN, supra note 9, at 155.

26 Başak ÇALi, The Authority of International LAW (2015); Nicole Roughan, Authorities (2013).

27 ÇALI, supra note 26, at 47.

${ }^{28}$ Felix Cohen, Transcendental Nonsense and the Functional Approach, 35 Colum. L. Rev. 809, 825 (1935).

29 ANNE ORFORD, INTERNATIONAL AUTHORITY AND THE RESPONSIBILITY TO PROTECT 195 (2011).

${ }^{30}$ Loughlin, supra note 9 , at 156, 160
} 